\title{
Evaluasi Biofermentasi Rumen Sapi Peranakan Ongole yang Diberi Pakan Berserat
}

\author{
W. P. S. Suprayogi \\ Program Studi Peternakan, Fakultas Pertanian, Universitas Sebelas Maret \\ Jl. Ir. Sutami 36A, Surakarta 57126
}

\begin{abstract}
ABSTRAK
Penelitian bertujuan untuk mengevaluasi nilai nutrisi dari berbagai hijauan pakan yaitu jerami kacang tanah, rumput raja dan hijauan jagung terhadap kemampuannya didalam menyediakan nutrien bagi ternak ditinjau dari fermentabilitas dalam rumen. Percobaan dilakukan secara in sacco untuk mengukur fermentabilitas pakan. Ternak yang digunakan dalam penelitian ini sebanyak 3 ekor sapi PO betina yang difistulasi pada bagian rumen untuk penetapan parameter fermentasi cairan rumen $\left(\mathrm{pH}, \mathrm{NH}_{3}, \mathrm{VFA}\right)$. Perlakuan yang diberikan adalah jenis hijauan pakan diberikan secara tunggal, hijauan tersebut adalah jerami kacang tanah (JKT), rumput raja (RR) dan hijauan jagung (HJ). Pemberian pakan dan minum secara ad libitum. Data parameter fermentasi rumen dianalisis dengan Rancangan Acak Lengkap pola searah. Hasil rerata selama 24 jam menunjukkan bahwa $\mathrm{pH}$ rumen pada sapi PO yang diberi pakan JKT, RR dan HJ nilai masingmasing sebesar 6,94, 6,68 dan 6,71, konsentrasi $\mathrm{NH}_{3}$ 13,71, 6,85 dan 4,37mg/100ml dan VFA total 48,99, 70,17 dan 51,59 mmol/l. Nilai $\mathrm{pH}$ dan konsentrasi $\mathrm{NH}_{3}$ dari ketiga jenis pakan menunjukkan pengaruh yang berbeda nyata $(\mathrm{p}<0,05)$, sedangkan konsentrasi VFA berbeda tidak nyata. Dari hasil penelitian dapat disimpulkan bahwa jerami kacang tanah memberikan kontribusi parameter fermentasi yang lebih baik dibanding rumput raja dan hijauan jagung.
\end{abstract}

Kata kunci : Sapi PO, hijauan pakan, nilai nutrisi, fermentasi rumen

\section{Evaluation of Rumen Fermentation of Peranakan Ongole Cattle Fed Various Fibrous Feeds}

\begin{abstract}
The experiment was conducted to evaluate the nutritional value of ground peanut straw, king grass and corn forage and their ability to provide nutrients for livestock in terms of rumen fermentation. Three rumen-fistulated $P O$ cattles were used to investigate rumen fermentation parameter ( $\left.\mathrm{pH}, \mathrm{NH}_{3}, \mathrm{VFA}\right)$. The cattles were fed ground peanut straw (PS), king grass (KG) and corn forage (CF) ad libitum as single feed. The values of rumen fermentation parameters were analyzed using Analysis of Variance of Completely Randomized Design. The result showed that rumen $\mathrm{pH}$, and of cattle fed with $\mathrm{PS}, \mathrm{KG}$ and $\mathrm{CF}$ were 6.94, 6.68 and 6.71, $\mathrm{NH}_{3}$ concentrations $13.71,6.85$ and $4.37 \mathrm{mg} / 100 \mathrm{ml}$, and total VFA concentrations 48.99, 70.17 and $51.59 \mathrm{mmol} / \mathrm{l}$, respectively. Values of $\mathrm{pH}$ and $\mathrm{NH}_{3}$ concentration were significantly different $(p<0.05)$ among treatments, meanwhile VFA concentration were not significantly different. Ground peanut straw resulted the highest rumen fermentation parameters.
\end{abstract}

Key words : Peranakan Onggole cattle, fibrous feed, nutritive value, rumen fermentation 


\section{PENDAHULUAN}

Jenis pakan yang diberikan pada ternak ruminansia akan berbeda dengan ternak unggas. Ternak ruminansia cenderung membutuhkan jenis pakan berserat, umumnya berupa golongan rumput-rumputan dan limbah pertanian yang mengandung sejumlah nutrien guna memenuhi kebutuhan tubuh. Pakan ternak ruminansia tidak bisa lepas dari pakan berserat karena dibutuhkan untuk menjaga keseimbangan ekologi rumen serta kerja sistem saluran pencernaan terutama pada lambung untuk pencernaan yang optimal. Hal ini berhubungan dengan lambung majemuk yang dimilikinya, khususnya di retikulorumen yang dihuni oleh berjuta-juta mikrobia yang berfungsi sebagai tempat terjadinya proses pencernaan fermentatif. Proses ini akan menghasilkan produk yang dimanfaatkan oleh induk semangnya. Namun hal lain yang perlu dipertimbangkan adalah sebagian besar 60 70\% pakan yang masuk akan terdegradasi oleh mikrobia rumen.

Pakan yang masuk kedalam lambung akan mengalami degradasi oleh mikrobia rumen. Produk akhir dari fermentasi karbohidrat adalah VFA (Volatile Fatty Acids) dengan komponen utama $\mathrm{C}_{2}, \mathrm{C}_{3}$ dan $\mathrm{C}_{4}$, sedangkan protein pakan yang terdiriu atas protein murni dan NPN (Non Protein Nitrogen) akan terfermentasi menjadi amonia. Sebagian besar VFA diabsorpsi oleh ternak sebagai sumber energi dan sebagian lain digunakan sebagai kerangka karbon bersama ammonia $\left(\mathrm{NH}_{3}\right)$ untuk sintesis protein mikroba. Protein mikroba yang telah mengalami lisis, dimanfaatkan oleh induk semangnya (host) sebagai sumber asam amino esensial. Namun, dalam proses fermentasi rumen juga menghasilkan produk samping berupa $\mathrm{CO}_{2}$ dan $\mathrm{CH}_{4}$, dimana pembentukan gas ini menyebabkan kerugian, karena ternak kehilangan sejumlah energi yaitu sebesar 6.5\% dari energi bruto (GE=Gross Energy).

Protein pakan yang masuk ke dalam rumen sebagian dihidrolisis menjadi peptida dan asam-asam amino oleh mikrobia rumen.
Besar kecilnya degradasi dalam rumen tergantung dari asal protein yang menunjukkan karakteristik fisiko-kemis, aktivitas mikrobia rumen(Widyobroto, et al, 1997). Asam-asam amino mengalami degradasi lebih lanjut dan deaminasi menjadi VFA $\mathrm{NH}_{3}$ dan $\mathrm{CO}_{2}$ (Orskov, 1982). $\mathrm{NH}_{3}$ yang terbentuk dari proses deaminasi dikombinasikan dengan asam organik alfa keto menjadi asam amino baru sebagai prekursor untuk sintesis $\mathrm{N}$ mikroba. Ternak yang mendapatkan pakan basal berserat kasar tinggi, produksi mikroba dalam rumen dibatasi oleh ketersediaan energi, protein mudah larut dan mineral terutama S dan $\mathrm{P}$ (Chuzaemi, 1994 dan Sauvant et al., 1997), Widyobroto (1992) melaporkan bahwa sintesis protein mikroba akan optimal bila pelepasan prekursor $\mathrm{N}$ dan kerangka karbon di rumen yang dibutuhkan oleh mikroba selaras atau sinkron.

Optimalisasi pertumbuhan mikrobia merupakan prioritas utama apabila pakan hanya diberikan hijauan tunggal, mengingat peranan mikrobia ini sangat penting dalam proses biofermentasi dalam rumen ditinjau dari kemampuannya dalam mendegradasi pakan serat sebagai pakan utamanya dan mikrobia rumen merupakan sumber protein berkualitas tinggi bagi induk semangnya (host)nya. Sekitar 40\% hingga 80\% dari kebutuhan protein ternak ruminansia dicukupi dari mikrobia rumen (Johnson, 1980; Czerkaswki, 1986), sehingga ternak mampu berproduksi sesuai dengan potensi genetiknya.

Mengingat peranan rumen sebagai tempat fermentasi dan perkembangbiakan mikrobia dan setiap macam bahan pakan mempunyai karakteristik tersendiri di dalam menghasilkan produk fermentasi rumen, maka tujuan dari penelitian ini untuk mengetahui parameter fermentasi rumen $\left(\mathrm{pH}, \mathrm{NH}_{3}, \mathrm{VFA}\right)$ pada sapi PO yang diberi pakan hijauan tunggal jerami kacang tanah, rumput raja dan hijauan jagung sehingga diperoleh karakter masingmasing bahan pakan dan dapat diketahui pula jenis suplmentasi yang cocok untuk masingmasing jenis pakan dalam penyediaan energi bagi ternak. 


\section{MATERI DAN METODE}

Ternak yang digunakan dalam penelitian ini sebanyak 3 ekor sapi PO betina yang difistulasi pada bagian rumen untuk penetapan parameter fermentasi cairan rumen. Sapi mempunyai bobot badan brkisar 210 - 230 kg dengan umur 1,5 - 2 tahun. Ternak dikandangkan pada kandang individual dengan ukuran 1,25 x 2 m yang dilengkapi dengan tempat pakan dan minum.Perlakuan yan $\mathrm{g}$ diberikan adalah jenis pakan hijauan yaitu tahap I : Jerami kacang tanah dengan umur panen 95 hari, tahap II : rumput raja umur potong 50 hari dan tahap III : hijauan jagung umur potong 70 hari. Komposis kimia bahan pakan dapat dilihat pada Tabel 1 .

Penelitian berlangsung 3 tahap.setiap tahap terdiri dari periode adaptasi 7-21 hari, dan periode koleksi selama 7 hari. Pada tahap pertama pakan diberikan jerami kacang tanah, tahap kedua rumput raja dan tahap ketiga hijauan jagung. Pengambilan sampel cairan rumen untuk pengukuran parameter fermentasi rumen dilakukan pada saat distribusi pakan pertama pada pukul 08.00 WIB, dengan kinetika waktu 0,1,2,3,4,6,8 jam setelah distribusi pakan. Setelah pengambilan cairan rumen langsung diukur $\mathrm{pH}$, selanjutnya diambil sampel untuk analisis $\mathrm{NH}_{3}$ sebanyak $5 \mathrm{ml}$ dengan ditambah pengawet5 $\mathrm{ml} \mathrm{NaCl} 20 \%$, sedangkan untuk VFA diambil $10 \mathrm{ml}$ cairan rumen ditambah $1 \mathrm{ml}$ pengawet $\mathrm{HgCl}_{2} \mathrm{H}_{3} \mathrm{PO}$, selanjutnya dibekukan pada suhu $-20^{\circ} \mathrm{C}$.

Data parameter rumen dianalisis variansi dengan menggunakan Rancangan Acak Lengkap pola searah. Bila ada perbedaan antar perlakuan dianalisis dengan uji beda Duncan (Astuti, 1980).

\section{HASIL DAN PEMBAHASAN}

\section{Kinetika pH Cairan Rumen}

Kinetika $\mathrm{pH}$ cairan rumen pada sapi $\mathrm{PO}$ yang diberi pakan hijauan tunggal JKT, RR dan HJ dapat dilihat pada Gambar 1.

Hasil analisis vaiansi kinetik $\mathrm{pH}$ cairan rumen ketiga jenis pakan menunjukkan pengaruh berbeda sangat nyata $(\mathrm{p}<0,01)$ pada 1 jam setelah distribusi pakan pertama berturutturut 7,35 : 6,72 dan 6,72 untuk JKT, RR dan HJ, dan waktu pengambilan selanjutnya menunjukkan perbedaan yang nyata $(\mathrm{p}<0,05)$ pada 2 jam $(7,15: 6,75 ; 6,71), \quad 3$ jam $(7,16: 6,76: 6,72)$ dan 6 jam $(7,05: 6,66: 6,71)$ setelah distribusi pakan pertama,sedangkan pada 4 jam (6,94:6,77:6,73) dan 5 jam (7,01:6,72:6,72) tidak menunjukkan perbedaan yang nyata. Berdasarkan uji Duncan JKT lebih tinggi $(\mathrm{p}<0,05)$ dari $\mathrm{RR}$ dan $\mathrm{HJ}$, sedangkan diantara keduanya tidak berbeda nyata. Kisaran $\mathrm{pH}$ dari ketiga jenis pakan masih berada pada kisaran yang normal untuk aktivitas fermentasi mikrobia rumen. Menurut Yokohama dan Johnson (1988) fermentasi rumen dapat berlangsung pada $\mathrm{pH}$ 6-7 dan temperature $38^{\circ}$ $42^{\circ} \mathrm{C}$. Umumnya $\mathrm{pH}$ cairan rumen pada ternak yang mengkonsumsi hijauan bervariasi 6,2-7 (Owens dan Goestch,1988).

Tabel 1. Komposisi kimia bahan pakan*

\begin{tabular}{llllcl}
\hline \hline Jenis bahan pakan & BK $(\%)$ & PK & LK & BETN & SK \\
\cline { 3 - 6 } & & \multicolumn{3}{c}{$\%$ BK } \\
\hline JKT & 20,35 & 13,89 & 1,85 & 44,56 & 26,90 \\
RR & 13,12 & 7,75 & 1,3 & 51,17 & 28,98 \\
HJ & 22,40 & 7,37 & 2 & 51,20 & 30,53 \\
\hline
\end{tabular}

*Hasil analisis laboratorium makanan ternak,Fakultas Peternakan UGM 


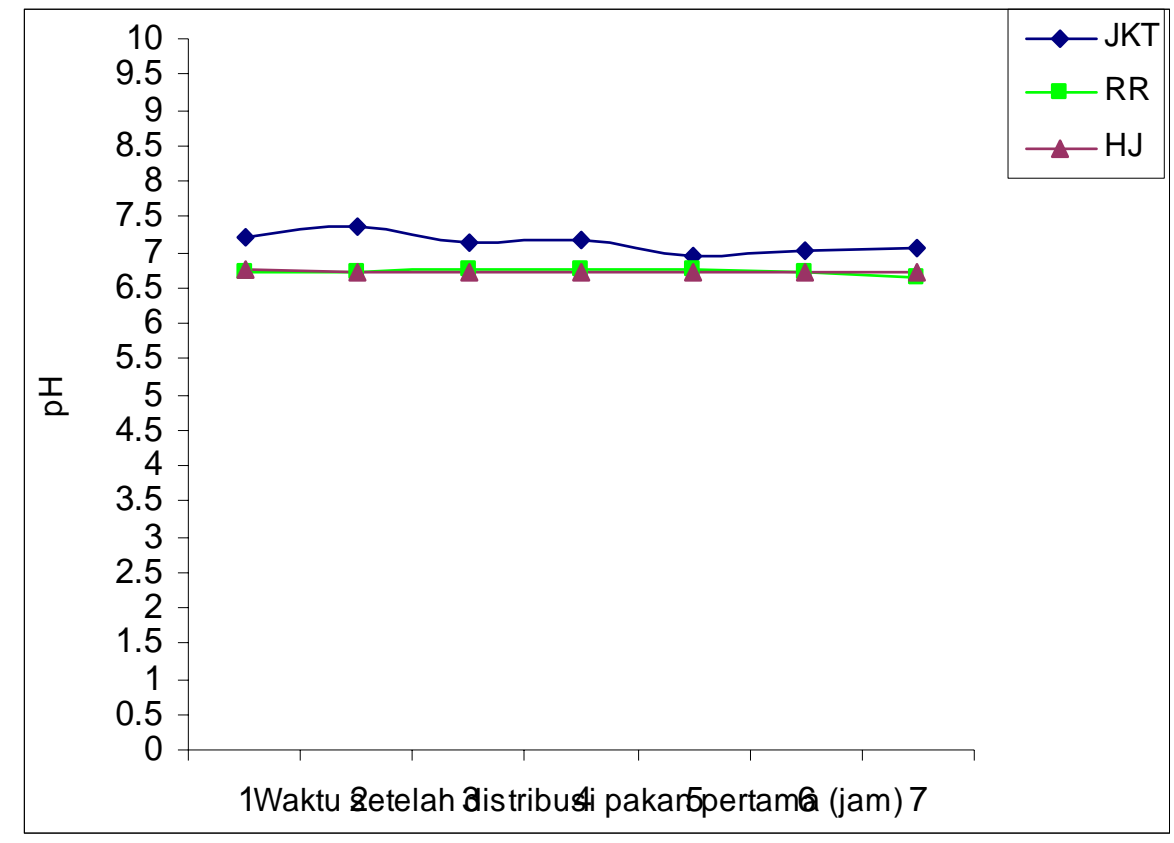

Gambar 1. Kinetika pH cairan rumen sapi PO

\section{Kinetika Konsentrasi $\mathrm{NH}_{3}$ cairan rumen}

Kinetika konsentrasi $\mathrm{NH}_{3}$ cairan rumen sapi PO yang diberi pakan hijauan tunggal JKT,RR dan HJ dapat dilihat pada Gambar 2.

Hasil analisis variansi kinetika $\mathrm{NH}_{3}$ untuk JKT, RR dan HJ menunjukkan pengaruh yang berbeda nyata $(\mathrm{p}<0,05)$ pada 1 jam $(19,64$; 10,66; 7,74 mg/100 ml), 2 jam(16,76; 10,54; 7,8 mg/100 ml), 3 jam (14,04; 10,32; 5’65 $\mathrm{mg} / 100 \mathrm{ml}$ ) dan 6 jam setelah distribusi pakan $(9,34 ; 5,52 ; 3,40 \mathrm{mg} / 100 \mathrm{ml})$ serta berbeda sangat nyata $(\mathrm{p}<0,01)$ pada 5 jam setelah distribusi pakan pertama(12,66; 6,98; 3,40 mg/100ml). Berdasarkan Duncan pakan JKT lebih tinggi $(\mathrm{p}<0,05)$ dari RR dan HJ.

Pola kinetika $\mathrm{NH}_{3}$ cairan rumen dari ketiga jenis pakan dicapai 1 jam setelah distribusi pakan, namun pada jam berikutnya sudah mengalami penurunan, hal ini berkaitan dengan absorbsi $\mathrm{NH}_{3}$ dan aktivitas mikrobia rumen. Konsentrasi ammonia dalam rumen selain dimanfaatkan untuk sintesis mikrobia, juga mengalami absorbsi melalui dinding rumen kemudian dibawa ke hati untuk recycle urea (McDonald et al., 1988; Reynolds, 1995).

\section{Kinetika total VFA cairan rumen}

Kinetika total asam lemak terbang (VFA) cairan rumen sapi PO yang diberi pakan hijauan tunggal JKT,RR dan HJ dapat dilihat pada Gambar 3.

Hasil analisis variansi kinetika VFA total ketiga jenis pakan menunjukkan pengaruh yang berbeda tidak nyata $(\mathrm{p}>0,05)$. Produksi VFA total setelah distribusi pakan pertama dari JKT adalah 59,09; 65,45 ; 66,26 ; 73,27 ; 64,09 ; 60,12 mmol/l, RR sebesar 84,23 ; 9,25 ; 85,51 ; 95,55 ; 85,96 ; 76,51 mmol/l dan HJ sebesar 54,12; 63,5 ; 76,27, 76,06; 69.09 ; 71,02 ; $67,36 \mathrm{mmol} / \mathrm{l}$. Hasil tersebut mengindikasikan bahwa ketiga jenis pakan dapat mendukung aktivitas mirobia dalam mencerna serat kasar dan menggambarkan ketersediaan energi bagi induk semang dan kerangka karbon untuk proses sintesis protein mikrobia. Menurut Widyobroto (1992) bahwa sintesis protein mikroba akan optimal apabila pelepasan prekursor $\mathrm{N}$ protein dan kerangka karbon dalam rumen yang dibutuhkan oleh mikroba selaras atau sinkron. 


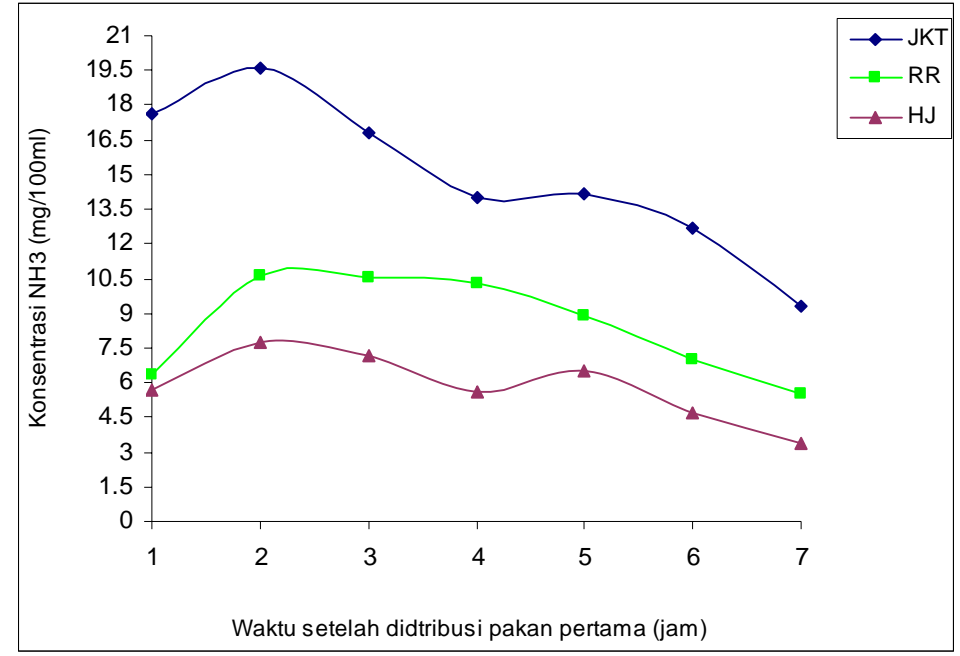

Gambar 2. Kinetika konsentrasi $\mathrm{NH}_{3}$ cairan rumen sapi PO

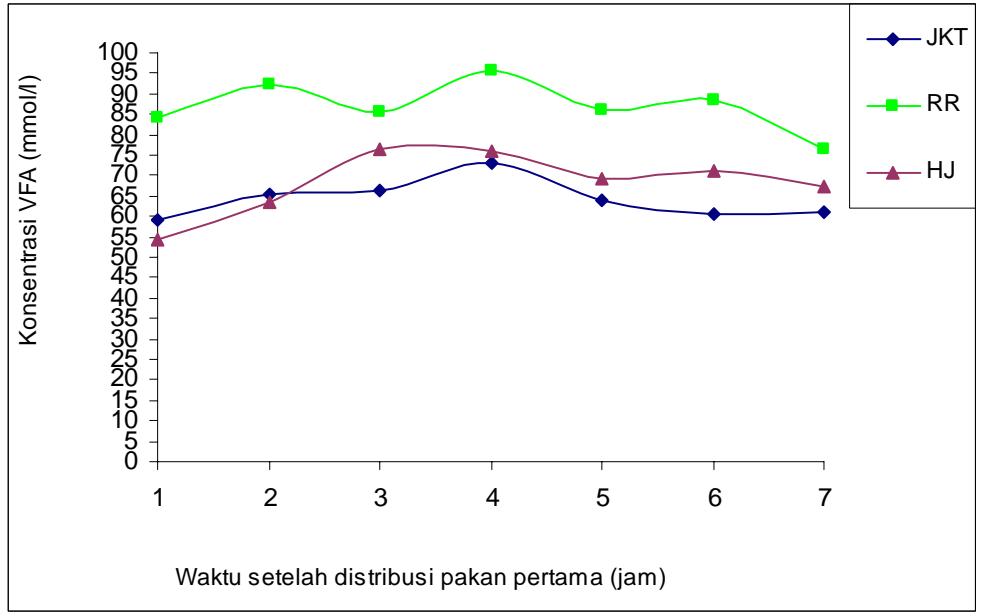

Gambar 3. Kinetika total VFA cairan rumen sapi PO

\section{KESIMPULAN}

Berdasarkan hasil penelitian dapat disimpulkan bahwa pakan jerami kacang tanah yang diberikan secara tunggal pada sapi Peranakan Ongole memberikan hasil parameter fermentasi rumen ( $\mathrm{pH}$, konsentrasi $\mathrm{NH}_{3}$ dan konsentrasi VFA) yang lebih tinggi dibandingkan rumput raja dan hijauan jagung tetapi produk fermentasi rumen dari ketiga jenis pakan masih pada kisaran yang normal untuk aktivitas mirobia dalam mencerna pakan berserat.

\section{DAFTAR PUSTAKA}

Astuti,M. 1980. Rancangan Percobaan dan Analisis statistic. Bagian PemuliaanTernak Fakultas Peternakan UGM, Yogyakarta.

Czerkaswki, J. W. 1986. An Introduction to Rumen Studies. Pergamon Press. Oxford.

Owens,F.N and A.L., 1988. Ruminant fermentation. : D.C. Church (Ed), The Ruminant animal. Prentice Hall, Englewood Cliifs, New Jersey. pp.145-171.

McDonald, P., R.A. Edwards and J.F.D. Greenhalg. 1988. Animal Nutrition. 4 th. Ed. Longman, London. 
Reynold, C.K. 1995. Quantitative aspects of liver metabolism in ruminant. In : Engelhards, W.V., S.Leonhard-Marek, G. Breves, D. Giesecke (Eds), Ruminant Physiology : digestion, Metabolisme, growth and Reproduction. Ferdinand enke verlag. Pp.351368.

Widyobroto, B. P. 1992. Pengaruh konsentrat dalam ransum terhadap kecernaan dan sintesis $\mathrm{N}$ mirobia di dalam rumen pada sapi perah produksi tinggi. Buletin Peternakan. Fakultas Peternakan UGM. Yogyakarta.
Reynold, C.K. 1995. Quantitative aspects of liver metabolism in ruminant. In : Engelhards, W.V., S.Leonhard-Marek, G. Breves, D. Giesecke (Eds), Ruminant Physiology : digestion, Metabolisme, growth and Reproduction. Ferdinand enke verlag. Pp.351368.

Yokoyama, M.T. and K.A. Johnson. 1988. Microbiology of the rumen digestive physiology and nutrition. In : D.C. Church (Ed.), The Ruminant animal. Printice Hall, Englewood Cliifs, New Jersey. pp. 125-144. 